\title{
Correlation between Amitriptyline-Induced Cardiotoxic Effects and Cardiac S100b Protein in Isolated Rat Hearts
}

\author{
Nil Hocaoğlu ${ }^{1}$, Nergis Murat², Serap Cilaker Mıcılı ${ }^{3}$, Burç Aydın², Bekir Uğur Ergür ${ }^{3}$, Şule Kalkan ${ }^{1}$ \\ ${ }^{1}$ Division of Clinical Toxicology, Department of Pharmacology, Dokuz Eylül University School of Medicine, İzmir, Turkey \\ ${ }^{2}$ Department of Pharmacology, Dokuz Eylül University School of Medicine, İzmir, Turkey \\ ${ }^{3}$ Deparment of Histology and Embryology, Dokuz Eylül University School of Medicine, İzmir, Turkey
}

Background: Amitriptyline is an important cause of mortality due to its cardiovascular toxicity.

Aims: To investigate the changes in levels of cardiac S100b protein on amitriptyline-induced cardiotoxicity and also to examine the correlation between amitriptyline-induced cardiotoxic effects and cardiac $\mathrm{S} 100 \mathrm{~b}$ protein in an isolated rat heart model.

Study Design: Animal experimentation, isolated heart model.

Methods: After a stabilization period, isolated hearts were randomized to two groups $(n=5$ and $n=7)$. In the control group, isolated hearts were subjected to an infusion of 5\% dextrose for 60 minutes. In the amitriptyline group, $5.5 \times 10^{-5} \mathrm{M}$ amitriptyline was infused for 60 minutes to achieve amitriptyline toxicity. After the infusion period, heart tissues were removed for histological examination.
Results: In comparison to control treatment, amitriptyline infusion decreased left ventricular developed pressure (LVDP), dp/dtmax and heart rate (HR) and significantly prolonged QRS duration $(p<0.05)$. The semiquantitative scores for $\mathrm{S} 100 \mathrm{~b}$ protein levels in amitriptyline-infused hearts were higher than in the control group $(\mathrm{p}<0.01)$. At the end of the experiment, in the amitriptyline-infused group, significant correlations were found between LVDP and S100b protein scores $(r=-0.807, p=0.003)$ and between QRS duration and $\mathrm{S} 100 \mathrm{~b}$ protein scores $(\mathrm{r}=0.859, \mathrm{p}=0.001)$.

Conclusion: Our results indicate that the $\mathrm{S} 100 \mathrm{~b}$ protein may be a helpful indicator or biomarker in studying the cardiotoxic effects of amitriptyline.

Keywords: S100b protein, amitriptyline, toxicity, isolated heart, rat
Amitriptyline is a tricyclic antidepressant (TCA) that causes fatal poisoning. The severe morbidity and mortality associated with amitriptyline overdose are well documented to result from cardiovascular toxicity, which involves conduction disturbances, arrhythmia and hypotension (1-3).

$\mathrm{S} 100 \mathrm{~b}$ is a glia-associated protein. While $\mathrm{S} 100 \mathrm{~b}$ is highly expressed in astrocytes, low concentrations of S100b are expressed in heart, gastrointestinal or vesical cells, adipocytes and melanocytes (4-7). It has been shown that serum S100b levels increase in several cardiac, vascular, neurologic and psychiatric conditions (8-10). A few number of studies has been carried out in the area of raised S100b protein levels or expressions in antidepressant treatment. Some researchers have paid attention to correlation between S100b and depression or therapeutic dose of antidepressant treatment (11-16). In our previous study, serum S100b level increased in amitripty-

This study has been presented as a poster at the $23^{\text {rd }}$ National Pharmacology Congress, $7^{\text {th }}$ Clinical Pharmacology Symposium and $6^{\text {th }}$ Clinical Toxicology Symposium, 7-10 September 2015, Ankara, Turkey.

Address for Correspondence: Dr. Nil Hocaoğlu, Division of Clinical Toxicology, Department of Pharmacology, Dokuz Eylül University School of Medicine, İzmir, Turkey Phone: 00-90-232-4123908_e-mail: nil.hocaoglu@deu.edu.tr

Received: 4 May 2015 Accepted: 7 January 2016

- DOI: 10.5152/balkanmedj.2016.150435

Available at www.balkanmedicaljournal.org

Hocaoğlu N, Murat N, Cilaker Mıcılı S, Aydın B, Ergür BU, Kalkan Ş. Correlation between amitriptyline-induced cardiotoxic effects and cardiac S100b protein in isolated rat hearts. Balkan Med J 2016;33:681-7. 
line poisoning and significant correlation between cardiotoxic effects induced by amitriptyline and S100b protein level was observed (17). Because total serum S100b level was measured in this in vivo toxicity rat model, we planned an isolated heart study to investigate the changes of cardiac tissue-originated $\mathrm{S} 100 \mathrm{~b}$ in amitriptyline-induced cardiotoxicity by immunohistochemical examination. Also, we aimed to examine the correlation between amitriptyline-induced cardiotoxic effects and cardiac S100b in the isolated heart model.

\section{MATERIALS AND METHODS}

This project was approved by the Dokuz Eylül University Local Ethical Committee for Animal Experiments. Twelve adult, male Wistar-Albino rats $(261.8 \pm 3.2 \mathrm{~g})$ were used in this randomized controlled experimental study. Before the experiments, all rats were fasted and allowed free access to water overnight.

\section{Preparation and measurements}

The animals were sacrificed by cervical dislocation. Each heart was excised via bilateral thoracotomy and placed in an ice-cold modified Tyrode buffer which was heparinized (glucose $10 \mathrm{mM}, \mathrm{NaCl} 128 \mathrm{mM}, \mathrm{CaCl}_{2} 1.36 \mathrm{mM}, \mathrm{KCl} 4.7 \mathrm{mM}$, $\mathrm{NaH}_{2} \mathrm{PO}_{4} 0.36 \mathrm{mM}, \mathrm{NaHCO}_{3} 20 \mathrm{mM}$ and $\mathrm{MgCl}_{2} 1 \mathrm{mM}, \mathrm{pH}$ 7.4) solution. The Tyrode buffer solution was oxygenated with $95 \% \mathrm{O}_{2}$ and $5 \% \mathrm{CO}_{2}$ mixture and filtered (40 $\mu \mathrm{m}$ Microaggregate filter; Bıçakçılar, İstanbul, Turkey). The heart was cannulated with a stainless steel cannula via the ascending aorta and retrogradely perfused with modified Tyrode buffer solution $\left(10 \mathrm{~mL} / \mathrm{min}, 37^{\circ} \mathrm{C}\right)$. To measure left ventricular developed pressure (LVDP), a balloon catheter filled with distilled water connected to a transducer (MLT844 Physiological Pressure Transducer, Interlab LTD; İstanbul, Turkey) was inserted into the left ventricle cavity. The balloon volume was adjusted so that the left ventricular end-diastolic pressure (LVEDP) was $10 \mathrm{mmHg}$ during the experiment (18-19).

Electrocardiography (ECG) was performed to measure QRS duration (Powerlab/8SP, AD Instruments; Oxford, UK). Heart rate (HR) and LVDP were measured automatically and maximum rates of LVDP development ( $\left.\mathrm{dp} / \mathrm{dt}_{\max }\right)$ as the first derivative of pressure was automatically calculated from the difference of LVDP.

Before the experiment, all hearts were allowed to stabilize for 15 minutes. After the stabilization period, baseline measurements were obtained; if hearts had LVDP $<70 \mathrm{mmHg}$ or were mechanically unstable, they were excluded from the experiment (18-19). The cardiac parameters (LVDP, $\mathrm{dp} / \mathrm{dt}_{\max }$, QRS duration and HR) were recorded continuously during the experimental protocol.

\section{Experimental protocol}

After stabilization period, isolated hearts were randomized into two groups. In control group (Group 1, $\mathrm{n}=5$ ), isolated hearts were subjected to an infusion of $5 \%$ dextrose for 60 minutes. In our previous isolated rat heart studies, $5.5 \times 10^{-5} \mathrm{M}$ amitriptyline infusion prolonged QRS duration by $50-75 \%$ (18-19). In the amitriptyline group (Group 2, n=7), the same dose $\left(5.5 \times 10^{-5} \mathrm{M}\right)$ of amitriptyline was infused for 60 minutes to achieve amitriptyline toxicity. After the infusion period ( $5 \%$ dextrose or amitriptyline), heart tissues were removed for histological examination.

\section{Histological examination}

After routine procedures the heart tissues were embedded in paraffin. The paraffin blocks were located in rotary microtome (RM 2255, Leica; İstanbul, Turkey). Five $\mu \mathrm{m}$ serial coronal sections were taken. All sections were stained with hematoxylin-eosin (H\&E) after deparaffinization and rehydration.

\section{Immunohistochemical (IHC) staining}

The immunohistochemistry procedure for S100b (Abcam, ab52642) was performed using a standard avidin-biotin complex method. Sections were dewaxed in xylene after they were incubated at $60^{\circ} \mathrm{C}$ overnight. After rehydrating through a decreasing series of ethanols, the sections were washed in distilled water. Sections were marked using a Pap-pen (Dako; Glostrup, Denmark). For antigen masking, microwave treatment was performed in citrate buffer ( $\mathrm{pH}$ 6.0). To inhibit endogenous peroxidase activity, sections were treated with $3 \% \mathrm{H}_{2} \mathrm{O}_{2}$ for 15 minutes and then with normal serum blocking solution. After this, sections were incubated in a humid chamber at $+4^{\circ} \mathrm{C}$ for 18 hours with primer antibody against $\mathrm{S} 100 \mathrm{~b}$ (diluted at 1/500). After this step sections were treated with biotinylated $\mathrm{IgG}$, and then streptavidin peroxidase for 15 minutes. All solutions were prepared according to the instructions of the manufacturer (859043, Invitrogen Corporation; Camarillo, UK). Sections were stained with diaminobenzidine (DAB) (1718096, Roche; Mannheim, Germany) and counterstained with Mayer's hematoxylin. Sections were dehydrated through a graded ethanol series, cleared in xylene, mounted in Entellan (Merck KGaA; Darmstadt, Germany). They were analyzed using a light microscope (20).

\section{Semi-quantitative scoring of immunostaining}

A semiquantitative grading system was used to score immunostaining as follows: 0 , no immunoreactivity; 1 , very few positive staining was observed in an image and the staining was mild; 2, positive staining was moderate and between grade 1 and grade $3 ; 3$, strong positive staining was evenly distributed in the whole image. To maintain consistency of scoring, each section was graded by two blind histologists to 
treatments. Average scores were used to represent the grade of immunostaining for each section (21).

\section{Drugs}

Amitriptyline (Sigma-Aldrich Company; Steinheim, Germany) was prepared as $10^{-3} \mathrm{M}$ stock solution in distilled water. Amitriptyline and 5\% dextrose were diluted in Tyrode solution before infusion. The drugs were infused using a pump (Braun PerfusorR compact S; Melsungen, Germany).

\section{Statistical analysis}

Shapiro-Wilk test was used for testing the normality of data. Statistical analyses were performed using percent changes in all cardiac parameters (LVDP, $\mathrm{dp} / \mathrm{dt}_{\text {max }}$, QRS duration and $\mathrm{HR}$ ). The analyses were done using the (GraphPad Instat ${ }^{\mathrm{TM}}$, 1990-1994, GraphPad Software V2.05a 9342; USA). Data within groups were evaluated by "repeated measures analysis of variance (ANOVA)" followed by Bonferroni's multiple comparison tests. Differences among groups were analyzed using unpaired Student's t-test. Because of the asystole of three hearts after 40 minutes in amitriptyline group, statistical analyses were performed at 10, 20, 30 and 40 minutes in each group. Mean values (mean \pm S.E.M.) and $95 \%$ confidence intervals $(95 \%$ CIs) were presented in the text. When $\mathrm{p}$ value was below 0.05 , it was considered as statistically significant.
The histological data were analyzed statistically using computer software Statistical Package for the Social Sciences version 15.0 (SPSS Inc.; Chicago, IL, USA). Averages of the results of the groups and standard deviations were measured using descriptive statistical methods. The statistical significance of differences between groups was performed by Kruskal Wallis and MannWhitney U test. Spearman correlation coefficients were calculated to analyze the correlation between all cardiac parameters and semi-quantitative immunostaining scores for S100b.

\section{RESULTS}

The weight and baseline measurements of cardiac parameters [(left ventricular developed pressure (LVDP), maximum rates of LVDP development ( $\left.\mathrm{dp} / \mathrm{dt}_{\max }\right)$, QRS duration and heart rate $(\mathrm{HR})]$ were similar for both group ( $\mathrm{p}>0.05$ for all, Table 1$)$.

\section{Cardiac parameters}

\section{Differences within treatment groups}

In the control group, the infusion of $5 \%$ dextrose for $60 \mathrm{~min}$ utes did not change any cardiac parameters in comparison to baseline ( $p>0.05$, Table 1). In Group 2, the amitriptyline infusion decreased LVDP by $40-55 \%$ at 10, 20, 30 and 40 min-

TABLE 1. The effects of 5\% dextrose or amitriptyline (5.5x10-5 M) infusion on left ventricular developed pressure, maximum rates of left ventricular developed pressure, QRS duration and heart rates

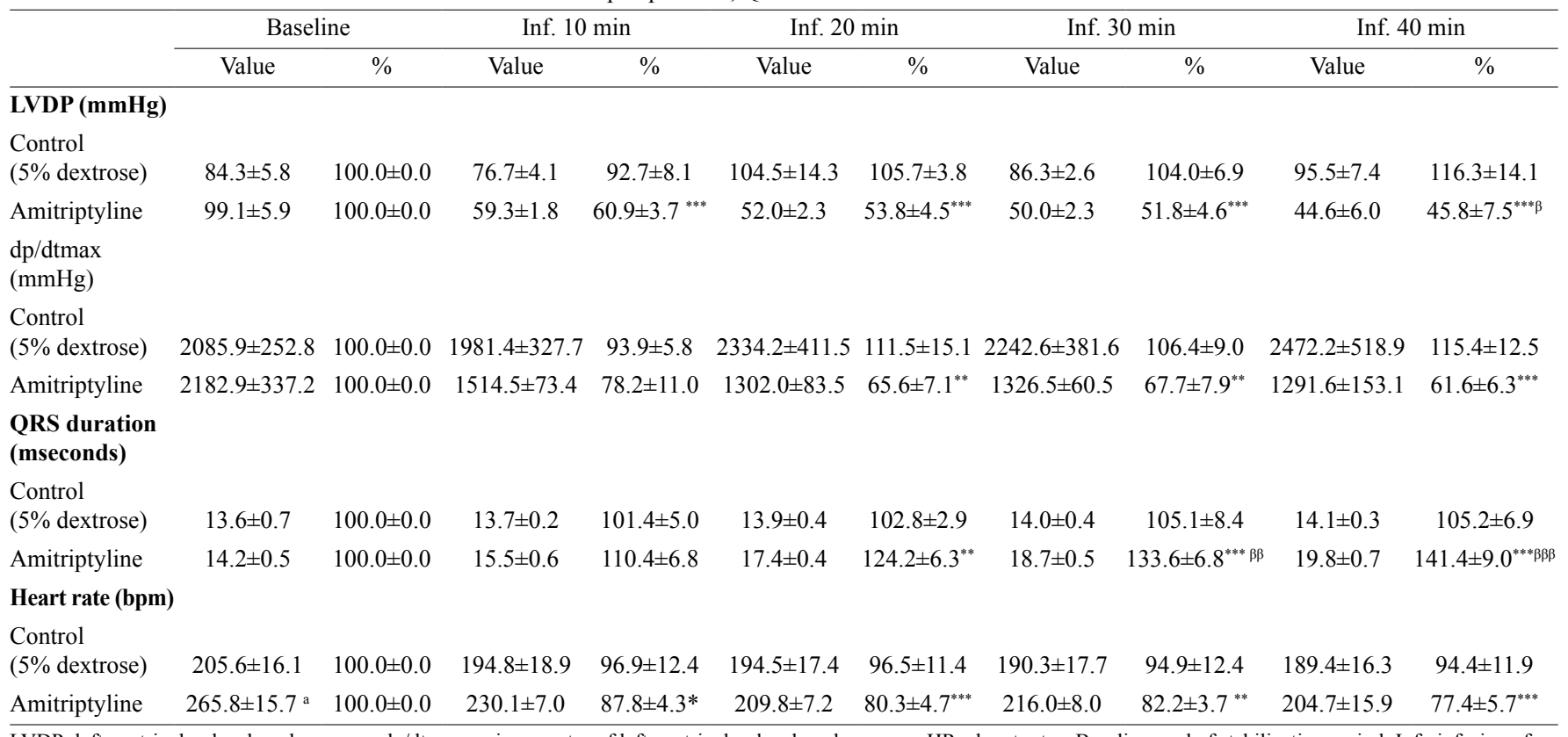

LVDP: left ventricular developed pressure; $\mathrm{dp}_{\mathrm{dt}_{\max }}$ : maximum rates of left ventricular developed pressure; HRs: heart rates; Baseline: end of stabilization period; Inf:: infusion of $5 \%$ dextrose or amitriptyline in control or amitriptyline groups, respectively

$* * * * \mathrm{p}<0.0001$ compared to baseline, ${ }^{* * *} \mathrm{p}<0.001$ compared to baseline, ${ }^{* *} \mathrm{p}<0.01$ compared the baseline, ${ }^{*} \mathrm{p}<0.05$ compared to baseline

${ }^{\beta} \mathrm{p}<0.05$ compared to inf. 10 . min., ${ }^{\beta \beta} \mathrm{p}<0.01$ compared to inf. 10 . min., ${ }^{\beta \beta} \mathrm{p}<0.001$ compared to inf. 10 . min.

${ }^{a}$ Mean HR values were higher in the amitriptyline group (approximately $25 \%$ ) compared to the control group. But, there was not any statistically significant difference between groups. 
utes when compared to the baseline values $(\mathrm{p}<0.001$, Table 1). The amitriptyline infusion significantly decreased the $\mathrm{dp} /$ $\mathrm{dt}_{\text {max }}$ after 20 minutes and also decreased HR after 10 minutes $(p<0.01$ and $p<0.05$, respectively; Table 1). QRS prolongation continued significantly during amitriptyline infusion after 20 min when compared to baseline values $(\mathrm{p}<0.01$, Table 1$)$.

\section{Differences among treatment groups}

The amitriptyline infusion significantly decreased LVDP at $10,20,30$ and $40 \mathrm{~min}$ when compared to the control group $(92.7 \pm 8.1 \%$ to $60.9 \pm 3.7 \%, 95 \%$ CI $13.9-49.6, \mathrm{p}<0.01$; $105.7 \pm 3.8 \%$ to $53.8 \pm 4.5 \%, 95 \%$ CI $37.9-65.9, \mathrm{p}<0.0001$; $104.0 \pm 6.9 \%$ to $51.7 \pm 4.6 \%, 95 \%$ CI $34.5-70.0, p<0.0001$ and $116.3 \pm 14.1 \%$ to $45.8 \pm 7.5 \%, 95 \%$ CI $37.6-103.2, p<0.001$, respectively, Figure 1). The $\mathrm{dp} / \mathrm{dt}_{\max }$ were decreased at 20,30 and 40 min significantly in amitriptyline group when compared to the control group $(111.5 \pm 15.1 \%$ to $65.6 \pm 7.1 \%, 95 \%$ CI $12.3-79.5, \mathrm{p}<0.05 ; 106.4 \pm 8.9 \%$ to $67.7 \pm 7.9 \%, 95 \%$ CI $11.7-65.6, \mathrm{p}<0.01$ and $115.4 \pm 12.5 \%$ to $61.6 \pm 6.3 \%, 95 \% \mathrm{CI}$ $25.2-82.4, \mathrm{p}<0.01$, respectively, Figure 2). When compared to the control group, QRS duration was significantly prolonged at 20,30 and $40 \mathrm{~min}$ of amitriptyline infusion $(102.8 \pm 2.9 \%$ to $124.2 \pm 6.3 \%, 95 \%$ CI $[-39.0]-[-3.8], \mathrm{p}<0.05 ; 105.1 \pm 8.4 \%$ to $133.6 \pm 6.8 \%, 95 \%$ CI $[-52.2]-[-4.7], \mathrm{p}<0.05$ and $105.2 \pm 6.9 \%$ to $141.4 \pm 8.9 \%, 95 \% \mathrm{CI}[-63.3]-[-9.1], \mathrm{p}<0.05$, respectively, Figure 3). There were no statistically significant differences in HR between control and amitriptyline groups $(\mathrm{p}>0.05)$.

\section{Histological results}

In hematoxylin-eosin (H\&E) staining of the hearth tissue sections, the cardiac muscle cells had a normal morphology in control group (Group 1). In the amitriptyline group (Group 2), the histomorphology of cardiac muscle cells was

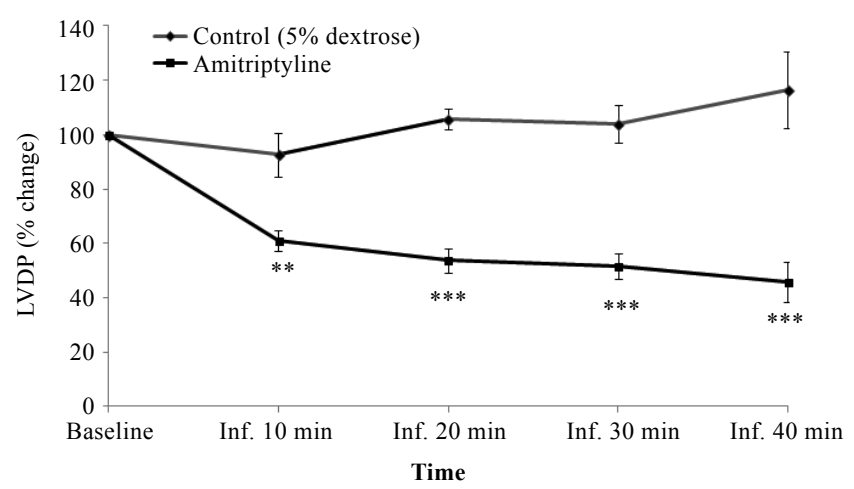

FIG. 1. Effects of $5 \%$ dextrose and amitriptyline infusions on left ventricular developed pressure (LVDP). Statistical analyses were performed using percentage changes in LVDP among groups. (Baseline: End of stabilization period)

$* * \mathrm{p}<0.001 ; * * * \mathrm{p}<0.0001$ versus control group similar to that observed in the control group; however, in some areas, rare myofibrillar degeneration and vacuoles were observed.

\section{Immunohistochemical results}

Immunostaining for $\mathrm{S} 100 \mathrm{~b}$ showed was positive in the perivascular area and in myocardial cell cytoplasm. Semi quantitative immunostaining scoring of S100b was significantly higher in amitriptyline group than the control group $(2.33 \pm 0.51$ and $0.8 \pm 0.44$, respectively, $p<0.01$, Figure 4 and Figure 5).

\section{Correlation between cardiac parameters and semi-quan- titative S100b immunostaining scores}

In the control group, there was not any significant correlation between semi-quantitative immunostaining scores of S100b protein and cardiac parameters (LVDP, $\mathrm{dp} / \mathrm{dt}_{\text {max }}$, QRS duration

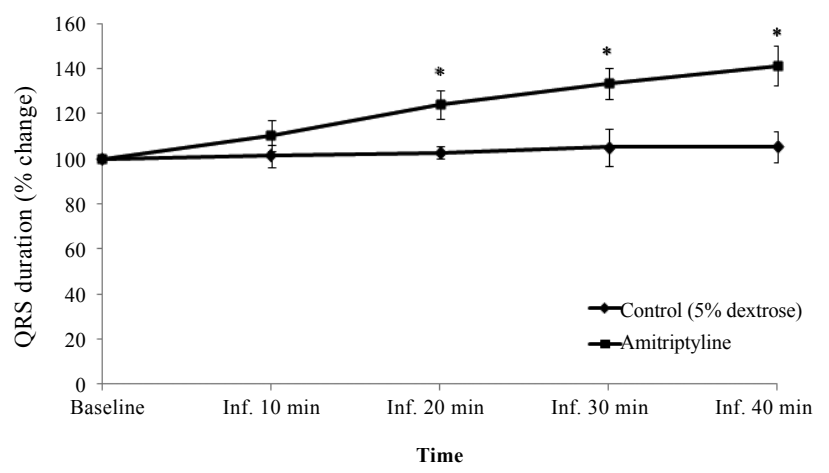

FIG. 2. Effects of $5 \%$ dextrose and amitriptyline infusions on maximum rates of left ventricular developed pressure (dp/dtmax). Statistical analyses were performed using percentage changes in $\mathrm{dp} / \mathrm{dtmax}$ among groups. (Baseline $=$ End of stabilization period)

${ }^{*} \mathrm{p}<0.05 ; * \mathrm{*}<0.01$ versus control group

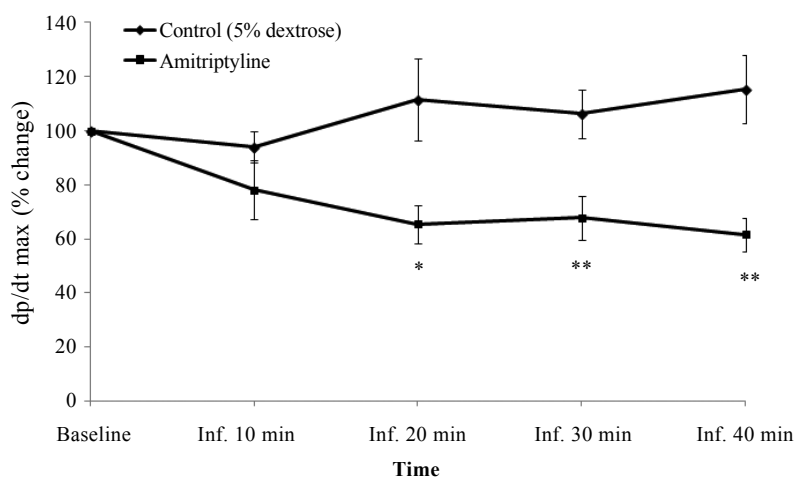

FIG. 3. Effects of $5 \%$ dextrose and amitriptyline infusions on QRS duration. Statistical analyses were performed using percentage changes in QRS duration among groups. (Baseline: End of stabilization period)

${ }^{*} \mathrm{p}<0.05$ versus control group 
Control (5\% Dextrose)
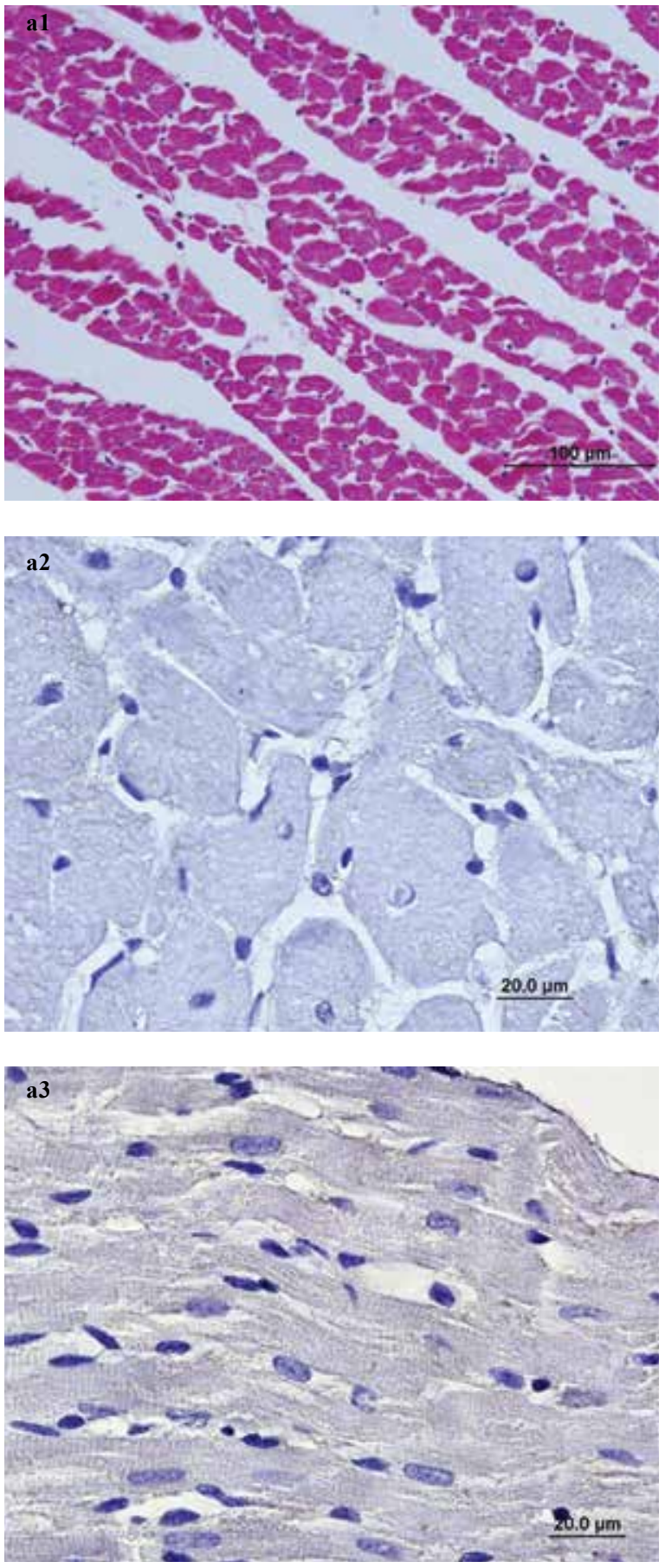
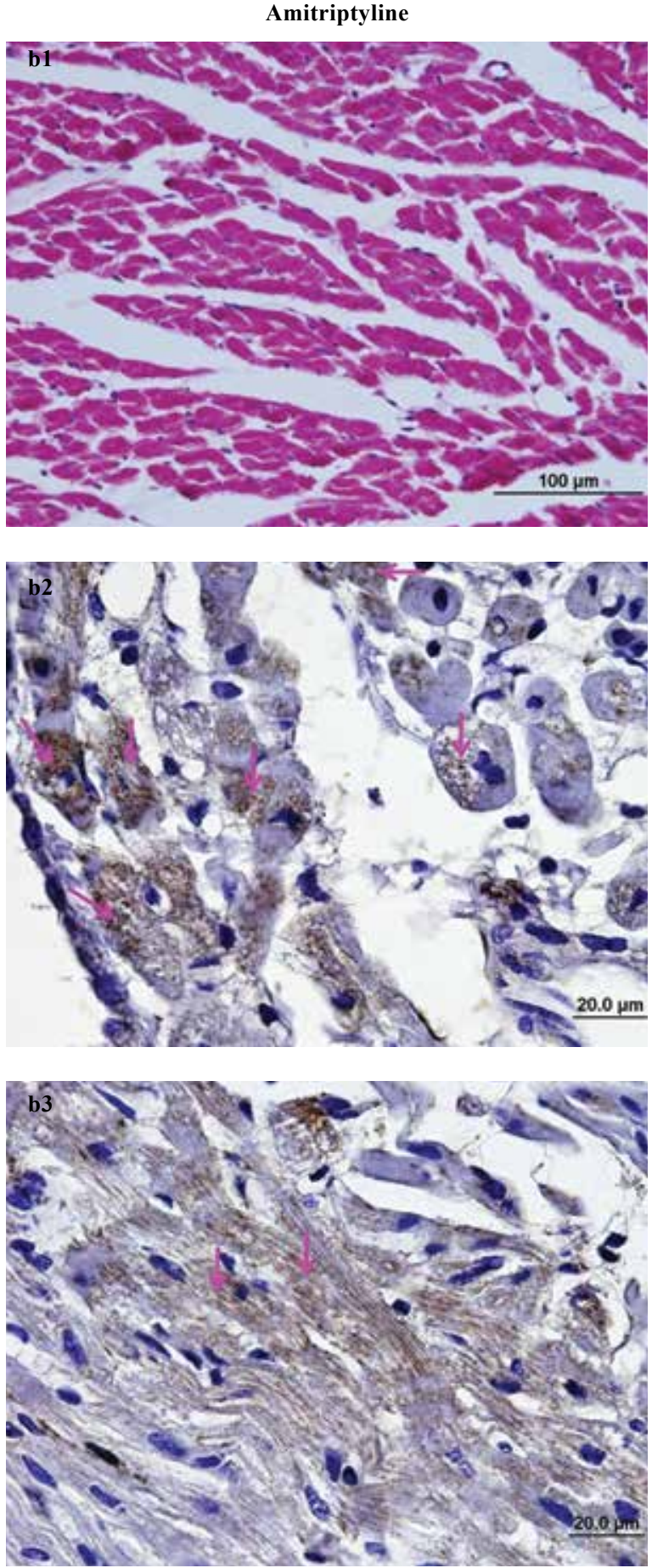

FIG. 4 a,b. Control group (Group 1) hematoxylin-eosin staining (a1). S100b protein immunohistochemical staining of control group (a2, a3). Amitriptyline group (Group 2) hematoxylin-eosin staining (b1). S100b protein immunohistochemical staining of amitriptyline group (b2, b3). Transverse sections of heart tissue (a2, b2). Longitudinal sections of heart tissue (a3, b3). Pink arrows show positive cells (b2, b3)

and HR) variations (Group 1). However, at the end of the experiment, a significantly very strong negative correlation was found for LVDP and S100b scores in amitriptyline infused group
(Group 2, $\mathrm{r}=-0.807, \mathrm{p}=0.003$ ). Also, there was a very strong positive correlation between QRS duration and S100b scores in Group 2, at the end of the experiment ( $\mathrm{r}=0.859, \mathrm{p}=0.001)$. 


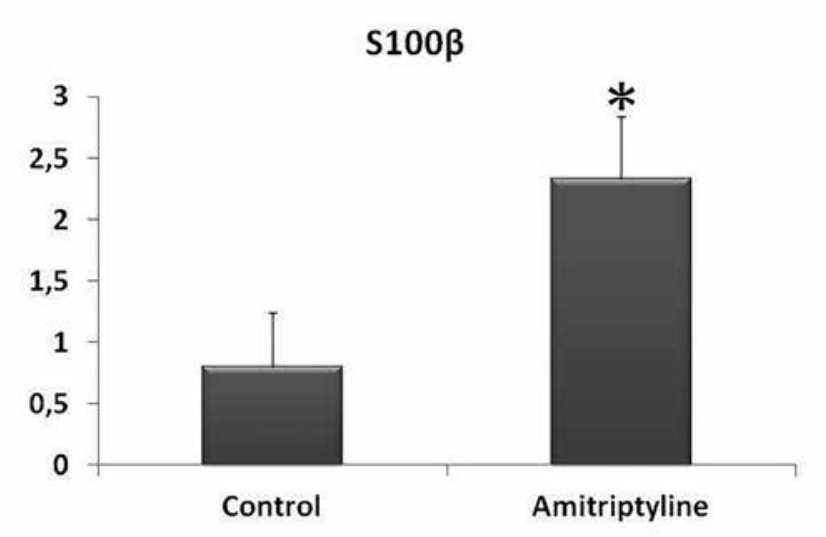

FIG. 5. Semiquantitative immunostaining scoring of $\mathrm{S} 100 \mathrm{~b}$ protein

\section{DISCUSSION}

This is the first study to evaluate the contribution of heart tissue to amitriptyline-induced $\mathrm{S} 100 \mathrm{~b}$ expression and the correlation between cardiac tissue-originated $\mathrm{S} 100 \mathrm{~b}$ protein and the cardiac effects of amitriptyline toxicity in an isolated rat heart model. In our previous isolated heart studies, we demonstrated that an amitriptyline infusion $\left(5.5 \times 10^{-5} \mathrm{M}\right)$ caused a significant prolongation of the QRS duration as an indicator of amitriptyline cardiotoxicity (18-19). In the present study, the same dose of amitriptyline $\left(5.5 \times 10^{-5} \mathrm{M}\right)$ infusion was used to achieve amitriptyline cardiotoxicity. The amitriptyline infusion caused a significant reduction in left ventricular developed pressure (LVDP) by approximately $50 \%$. Also, maximum rates of LVDP development $\left(\mathrm{dp}_{\mathrm{d}} \mathrm{dt}_{\max }\right)$ and heart rates (HRs) were decreased and QRS duration was prolonged significantly during amitriptyline infusion. The histological examination of heart tissues were performed for changes of the S100b immunostaining in amitriptyline-induced cardiotoxicity. The semi-quantitative scores for S100b immunostaining of amitriptyline-treated hearts were found to be significantly higher than control group. Also, at the end of the experiment, we found a significant very strong negative correlation between LVDP and S100b scores and, a very strong positive correlation between QRS duration and S100b scores in amitriptyline infused group, respectively.

Cardiovascular toxicity is the leading cause of death associated with amitriptyline overdose. Patients with serious overdoses may develop cardiovascular toxic effects. In patients with neurological symptoms such as lethargy and seizures or with cardiovascular symptoms such as dysrhythmia, hypotension, and electrocardiogram (ECG) changes (especially QRS prolongation), amitriptyline poisoning should be suspected. In previous studies, authors reported that ECG parameters (a QRS duration greater than $100 \mathrm{~ms}$ and a rightward T40 ms axis) may be used as a better indicator than the plasma TCA level $(1,22)$. However, Buckley et al. (23) reported a weak correlation between electrocardiogram data and the risk of arrhythmia after antidepressant poisoning. Serum tricyclic antidepressant levels may be used to help establish poisoning in patients known to be taking tricyclic antidepressants, but there is poor correlation between serum levels and clinical effects. Consequently, a helpful indicator or a serum biomarker that supports the electrocardiogram parameters is required for the diagnosis or monitoring of amitriptyline-induced cardiotoxic effects. In our previous study, the total serum S100b level increased in amitriptyline toxicity while S100b levels were correlated with cardiovascular toxic effects induced by amitriptyline in an in vivo model. Considering our previous results, it seems that raised levels of S100b in the serum may be associated with cerebral and extra cerebral sources, including heart tissue (17).

S100B is primarily expressed by the brain tissue but is also expressed by myocardial cells. Previous clinical and experimental studies showed that serum S100b levels increase in coronary artery bypass grafting, carotid endarterectomy and myocardial ischemia $(9,24-26)$. The data about the increase of S100b levels or expressions in isolated heart tissue is limited. Mazzini et al. pointed that ischemic heart released S100b in an isolated rat heart model (10). In our isolated heart study, we showed that the contribution of cardiac tissue-originated S100b increase in amitriptyline-induced toxicity with immunohistochemical findings. According to our histological findings, the presence of the positive immunostaining of S100b in the perivascular area and in myocardial cells cytoplasm show that cardiac-originated S100b increases in amitriptyline toxicity. We also found a significant correlation between semiquantitative immunostaining scores for $\mathrm{S} 100 \mathrm{~b}$ and the cardiac parameters impaired by amitriptyline poisoning (LVDP and QRS duration) after amitriptyline toxicity.

Serum S100b protein levels increase in major depression and after acute or chronic treatment with antidepressants $(8,12,14)$. In the present study, acute toxicity of amitriptyline mimicking accidental or suicidal overdose was evaluated. Our results cannot be extrapolated to chronic amitriptyline poisonings.

In conclusion, our results show that $\mathrm{S} 100 \mathrm{~b}$ protein may be a helpful indicator or a biomarker for amitriptyline-induced cardiotoxic effects. However, it is not clear whether this S100b increase was due to overexpression of the $\mathrm{S} 100 \mathrm{~b}$ protein followed by raised excretion, or to its leakage as a result of the amitriptyline-induced myocardial injury. Additionally, to rule out other causes that increase serum S100b protein levels, we need a well-designed prospective clinical study in patients presenting with acute amitriptyline poisoning who are admitted to the emergency department. 
Ethics Committee Approval: Ethics committee approval for this study was received from the ethics committee of Dokuz Eylül University School of Medicine.

\section{Informed Consent: N/A.}

Peer-review: Externally peer-reviewed.

Author contributions: Concept - N.H., Ş.K.; Design - N.H., Ş.K.; Supervision - N.H., B.U.E., Ş.K.; Materials - N.H., N.M., B.A., S.C.M.; Data Collection and/or Processing - N.H., N.M., B.A., S.C.M.; Analysis and/or Interpretation - N.H., N.M.; Literature Search - N.H., N.M., B.A.; Writing - N.H., S.C.M.; Critical Reviews - N.H., B.U.E., Ş.K.

Conflict of Interest: No conflict of interest was declared by the authors.

Financial Disclosure: This project was supported by Research Foundation of Dokuz Eylül University (grant number: 2012.KB.SAG.64).

\section{REFERENCES}

1. Thanacoody HK, Thomas SH. Tricyclic antidepressant poisoning: cardiovascular toxicity. Toxicol Rev 2005;24:205-14. [CrossRef]

2. Pimentel L, Trommer L. Cyclic antidepressant overdoses. Emerg Med Clin North Am 1994;12:533-47.

3. Shannon M, Liebelt EL. Toxicology reviews: Targeted management strategies for cardiovascular toxicity from tricyclic antidepressant overdose: The pivotal role for alkalinization and sodium loading. Pediatr Emerg Care 1998;14:293-8. [CrossRef]

4. Gürsoy M, Büyükuysal RL. Mechanism of S100b release from rat cortical slices determined under basal and stimulated conditions. Neurochem Res 2010;35:429-36. [CrossRef]

5. Donato R. S100: a multigenic family of calcium-modulated proteins of the EF-hand type with intracellular and extracellular functional roles. Int J Biochem Cell Biol 2001;33:637-68. [CrossRef]

6. Kahn HJ, Baumal R, Van Eldik LJ, Dunn RJ, Marks A. Immunoreactivity of S100 beta in heart, skeletal muscle, and kidney in chronic lung disease: possible induction by cAMP. Mod Pathol 1991;4:698-701.

7. Tsoporis JN, Marks A, Kahn HJ, Butany JW, Liu PP, O'Hanlon $\mathrm{D}$, et al. Inhibition of norepinephrine-induced cardiac hypertrophy in S100beta transgenic mice. J Clin Invest 1998;102:160916. [CrossRef]

8. Rothermundt M, Arolt V, Wiesmann M, Missler U, Peters M, Rudolf S, et al. S-100B is increased in melancholic but not in non-melancholic major depression. J Affect Disord 2001;66:8993. [CrossRef]

9. Tsoporis JN, Mohammadzadeh F, Parker TG. S100B: a multifunctional role in cardiovascular pathophysiology. Amino Acids 2011;41:843-7. [CrossRef]

10. Mazzini GS, Schaf DV, Oliveira AR, Gonçalves CA, BellóKlein A, Bordignon S, et al. The ischemic rat heart releases S100B. Life Sci 2005;77:882-9. [CrossRef]
11. Haring JH, Hagan A, Olson J, Rodgers B. Hippocampal serotonin levels influence the expression of S100 beta detected by immunocytochemistry. Brain Res 1993;631:119-23. [CrossRef]

12. Manev R, Uz T, Manev H. Fluoxetine increases the content of neurotrophic protein $\mathrm{S} 100 \mathrm{~b}$ in the rat hippocampus. Eur J Pharmacol 2001;420:R1-2. [CrossRef]

13. Manev H, Uz T, Manev R. Glia as a putative target for antidepressant treatments. J Affect Disord 2003;75:59-64. [CrossRef]

14. Akhisaroglu M, Manev R, Akhisaroglu E, Uz T, Manev H. Both aging and chronic fluoxetine increase $\mathrm{S} 100 \mathrm{~B}$ content in the mouse hippocampus. Neuro Report 2003;14:1471-3. [CrossRef]

15. Manev R, Manev H. Could treatment with arundic acid (ONO2506) increase vulnerability for depression? Med Hypotheses 2006;67:1170-2. [CrossRef]

16. Manev H, Manev R. Olanzapine and S100 proteins. Neuropsychopharmacology 2006;31:2567. [CrossRef]

17. Hocaoglu N, Kalkan S, Buyukdeligoz M, Oransay K, Tuncok Y. Is serum S100B protein a biomarker for amitriptyline-induced cardiovascular toxic effects? Cardiovasc Toxicol 2012;12:11522. [CrossRef]

18. Akgun A, Kalkan S, Hocaoglu N, Gidener S, Tuncok Y. Effects of adenosine receptor antagonists on amitriptyline-induced QRS prolongation in isolated rat hearts. Clin Toxicol (Phila) 2008;46:677-85. [CrossRef]

19. Akgun Arici MA, Kalkan S, Demir O, Hocaoglu Aksay N, Gidener S, Tuncok Y. Does adenosine A(1) receptor stimulation causes QRS prolongation by blocking beta adrenergic receptors in amitriptyline poisoning? Toxicol Lett 2009;186:130-8. [CrossRef]

20. Micili SC, Goker A, Sayin O, Akokay P, Ergur BU. The effect of lipoic acid on wound healing in a full thickness uterine injury model in rats. J Mol Hist 2013;4:339-45. [CrossRef]

21. Tuzun F, Gencpinar P, Ozbal S, Dilek M, Ergur BU, Duman N, et al. Neuroprotective effect of neotrofin in a neonatal rat model of periventricular leukomalacia. Neurosci Lett 2012;520:6-10. [CrossRef]

22. Olgun H, Yildirim ZK, Karacan M, Ceviz N. Clinical, electrocardiographic, and laboratory findings in children with amitriptyline intoxication. Pediatr Emerg Care 2009;25:170-3. [CrossRef]

23. Buckley NA, Chevalier S, Leditschke IA, O'Connell DL, Leitch J, Pond SM. The limited utility of electrocardiography variables used to predict arrhythmia in psychotropic drug overdose. Crit Care 2003;7:R101-7. [CrossRef]

24. van Boven WJ, Morariu A, Salzberg SP, Gerritsen WB, Waanders FG, Korse TC, et al. Impact of different surgical strategies on perioperative protein $\mathrm{S} 100 \beta$ release in elderly patients undergoing coronary artery bypass grafting. Innovations (Phila) 2013;8:230-6. [CrossRef]

25. Di Legge S, Di Piero V, Di Stani F, Perna R, Gattuso R, Reale MG, et al. Carotid endarterectomy and gliofibrillar S100b protein release. Neurol Sci 2003;24:351-6. [CrossRef]

26. Tsoporis JN, Izhar S, Leong-Poi H, Desjardins JF, Huttunen HJ, Parker TG. S100B interaction with the receptor for advanced glycation end products (RAGE): a novel receptor-mediated mechanism for myocyte apoptosis postinfarction. Circ Res 2010;106:93-101. [CrossRef] 